\title{
Fasülye Bitkisinin (Phaseolus vulgaris L. var. nanus) Demirli Gübrelemeye Responsu ile Toprakların Kloroz İndis Değerleri ve Bazı Özellikleri Arasındaki ílișkiler
}

\author{
Havva Sera ȘENDEMIRCi $\quad$ Ahmet KORKMAZ2* Güney AKINOĞLU²
}

'Toprak Gübre ve Su Kaynakları Merkez Araștırma Enstitüsü, Ankara

²Ondokuz Mayıs Üniversitesi, Ziraat Fakültesi, Toprak Bilimi ve Bitki Besleme Bölümü, Samsun

*Sorumlu yazar e-posta (Corresponding author e-mail) : akorkmaz@omu.edu.tr

Geliș tarihi (Received) : 31.03 .2016

Kabul tarihi (Accepted): 27.04.2016

\section{Öz}

Bu araștırmada, fasülye bitkisinin demirli gübrelemeye responsu ile toprakların kloroz indis değerleri ve bazı özellikleri arasındaki ilișkilerin belirlenmesi amaçlanmıștır. Bafra, Çarșamba ve Suluova'dan 0-20 $\mathrm{cm}$ derinlikten alınan toprak örneklerinin bazı fiziksel ve kimyasal özellikleri ile alınabilir demir ve kloroz indis değerleri tespit edilmiștir. Fasülye bitkisinin demirli gübrelemeye responsunu belirlemek için, sera șartlarında deneme topraklarına $\mathrm{Fe}_{0}: 0$ (kontrol), $\mathrm{Fe}_{1}: 2, \mathrm{Fe}_{2}: 4$ ve $\mathrm{Fe}_{3}: 8 \mathrm{mg} \mathrm{kg}^{-1}$ dozlarında Fe-EDDHA formunda demir (Fe) uygulanmıștır. Fe-EDDHA uygulanmasıyla fasülye kuru madde miktarı toprakların kireç kapsamları arttıkça artmıștır. Toprakların toplam ve aktif kireç kapsamları arttığında, yarayıșlı demir kapsamlarının azaldığı ve toprakların kloroz indis değerlerinin (indis-1 ve indis-2) arttığı belirlenmiștir. Toprakların kloroz indis değerleri arttıkça, uygulanan demirli gübrenin kontrole göre bitkinin kuru madde miktarında sağladığı artıș oranları yükselmiștir. Toprakların kum kapsamlarının artmasıyla yarayıș̦lı demir azalırken, artan organik madde miktarı yarayıșıı demir kapsamlarını artırmıștır.

Anahtar Kelimeler: Alınabilir demir, fasülye, Fe-EDDHA, kloroz indis değerleri, toplam ve aktif kireç

\section{The Relationships between Response of Beans (Phaseolus vulgaris L. var. nanus) Plant to Iron and Chlorosis Indices Values and Some Properties of Soils}

\begin{abstract}
The aim of this research was to determine iron fertilization response of beans plants and the relationship between chlorosis indices values and some properties of soils. Soil samples taken from 0-20 $\mathrm{cm}$ depth of agricultural lands from Bafra, Çarșamba and Suluova districts were determined some physical and chemical properties and iron chlorosis index values. $\mathrm{Fe}_{0}$ : 0 (control), $\mathrm{Fe}_{1}: 2, \mathrm{Fe}_{2}: 4 \mathrm{ve} \mathrm{Fe}_{3}: 8 \mathrm{mg} \mathrm{kg}^{-1}$ doses of Fe-EDDHA in the form of iron (Fe) were applied to the experiment soils in the greenhouse conditions to detect respons to the iron fertilization of bean plants. As the lime of soils increased, the amount of beans dry matter with Fe-EDDHA application increased. When total and active lime content of the soils have increased it is determined that a decrease in the available iron contents and an increase in the chlorosis indices 1 and 2 values of soils. As the chlorosis indices- 1 and indices- 2 values of soils
\end{abstract}


increased, the rate increase of dry matter amount with iron application compared to the control $\left(\mathrm{Fe}_{0}\right)$ increased. While increasing sand content of soil led to a reduction of plant-available iron, increasing organic matter content resulted rising plant-available iron.

Key Words: Available iron, bean, Fe-EDDHA, chlorosis indice values, total and active lime

\section{Giriș}

Cözelti kültürleri ve toprakla yapılan araștırmalar, çeșitli etmenlerin bitkilerde demir klorozuna neden olabildiğini göstermiștir. Toprakta ve bitki gelișme ortamında yüksek $\mathrm{pH}$, toprakta așırı miktarda kalsiyum ve magnezyum karbonat ve bikarbonatlar, kireçli topraklarda așırı nem, sulama sularında fazla bikarbonat iyonu, toprakta kötü havalanma durumu, yarayıșlı demir miktarının düșüklüğü, kök ortamında așırı fosfor ve așırı miktarda $\mathrm{Cu}, \mathrm{Zn}, \mathrm{Mn}, \mathrm{Co}, \mathrm{Ni}, \mathrm{Cd}$ gibi ağır metal iyonları, așırı nitrat azotu uygulaması, bitki çeșitlerinin kloroza duyarlıı̆̆ı, sıcaklıktaki ekstrem değerler ve yüksek ıșık intensitesi, organik maddenin çok düșük ya da çok yüksek olması, nematodlar ve virüsler gibi etmenler bitkilerde demir klorozuna sebep olabilmektedir (Özgümüș, 1987).

Demir klorozuna neden olan çeșitli faktörler arasındaki ilișkinin belirlenmesi sorunun çözümünde büyük önem tașımaktadır. Genetik kontrol, kloroza neden olan çevre koșullarının düzeltilmesi ve toprağa veya yapraklara demirli gübrelerin uygulanması gibi önlemler demir klorozunu önlemek veya gidermek üzere uygulanan ișlemlerden bazılarıdır (Özgümüș, 1987; Bașar, 1997).

Demir klorozunu noksanlığının giderilmesi diğer bitki besin maddesi elementlerine göre daha zor ve maliyeti yüksek olan bir ișlemdir. Kireçli topraklarda demir noksanlığı ile karșılașılabilmektedir. Bitki tür ve çeșitleri arasında demir klorozuna duyarlıık yönünden çok farklılıklar bulunduğundan dolayı, bu tip topraklarda kloroza toleranslı veya dayanıklı bitki tür ve çeșitlerinin yetiștirilmesi gerekmektedir. Bitkilerde demir noksanlığını gidermek üzere kullanılan en güvenilir demir kaynakları șelatlardır. Șelatların alkalin topraklarda bitkilere demir sağlama derecesi, șelatların çeșitli $\mathrm{pH}$ düzeylerindeki stabilitelerine bağlıdır (Norvell, 1972). Șelatlar içerisinde kireçli topraklar için en etkin demir kaynağı Fe-EDDHA'dır (Loué, 1986). Ancak demir șelatların maliyetinin yüksek olması sebebiyle, mutlaka intiyaç halinde kloroz riski tașıyan arazilerde ve bitkilerde kullanılmalıdır. Bunu sağlamak için arazilerin önceden demir kloroz riski tașıyıp tașımadıkları tespit edilmelidir.
Cox ve Kamprath (1972) tarafindan topraklarda demir kloroz intimalinin ortaya konulmasında toplam kireç kapsamının tek bașına belirleyici bir indeks olamayacağı belirtilmiștir. Araștırıcılar toprakların yarayıșlı demir kapsamlarının belirlenmesinde ekstraksiyon yöntemlerinin kullanılması gerektiğini de bildirmișlerdir. Loué (1986), toprakların demir klorozu gösterme güçlerinin bir ölçüsü olarak, toprakta aktif kirecin belirlenmesi gerektiğini bildirmiștir. Juste ve Pouget (1972) tarafından sadece aktif kirecin değil, toprakların kloroz indeks değerlerinin belirlenmesinin de önemli olduğu belirtilmiștir. Araștırıcılar bu indeksin belirlenmesinde toprakların aktif kireç kapsamı ile amonyum oksalatla kolayca ekstrakte edilebilir demir kapsamını kullanmıșlardır. Bulunan indeks değerlerinin özellikle asma bahçesi topraklarında kloroz riskinin ortaya konulmasında kullanıldığını belirtmișlerdir.

Morlat ve Courbe (1981) indis formülündeki kolayca ekstrakte edilebilir demiri belirlemek için amonyum okzalat ekstraksiyon yöntemi yerine EDTA ekstraksiyon yönteminin kullanılabileceğini, EDTA ile ekstrakte edilebilir demir değerlerinin kullanılması halinde belirlenen indis değerlerinin bitkinin demir sağlama durumunu ve toprakların demir kloroz riskini daha iyi göstereceğini bildirmișlerdir.

Champagnol (1984), toprakta aktif kalkerin ve kloroz indis değerlerinin eșik değerlerinin asma anaçlarına göre değiștiğini, aktif kireç için eșik değerlerinin anaçlara göre değișmekle beraber \% 640 arasında olduğunu, kloroz indis değerleri için eșik değerlerinin anaçlara göre değișmekle beraber 5120 arasında olduğunu belirtmiștir.

Boer ve Reisenauer (1973), DTPA yöntemi için kritik demir düzeyinin 5-6 mg kg-1 olduğunu, bu seviyenin üzerinde demir içeren topraklarda demir klorozu görülmediğini tespit etmișlerdir. Buna karșın Lindsay ve Norvell (1969), tarafından belirtilen $0,005 \mathrm{M} \mathrm{DTPA}+0.01 \mathrm{M} \mathrm{CaCl}_{2}+0,1 \mathrm{M}$ Triethanolamin $(\mathrm{pH}: 7.3)$ yöntemi için kritik değer Lindsay (1979) tarafindan $4.5 \mathrm{mg} \mathrm{kg}^{-1}$ bildirilmiștir. Araștırıcı, $4.5 \mathrm{mg}$ $\mathrm{kg}^{-1}$ üzerinde demir içeren topraklarda demirli gübrelemeye respons alınmadığını da belirtmiștir. 
Lindsay (1974), kalkerli topraklar için en iyi demirli gübrenin Fe-EDDHA olduğunu, Loué (1986), demir noksanlığını önlemek için topraktan uygulanan demir șelatları arasındaki etkinlik farkının yüksek pH'ı topraklarda șelatların stabiliteleri ile ilgili olduğunu belirtmiștir. Fe-EDDHA șelatının bütün pH'larda stabil kaldığını, Fe-EDTA șelatının $\mathrm{pH}$ 6.3'ün üzerinde stabilitesinin bozulduğunu, Fe-DTPA șelatının ise $\mathrm{pH}$ $7.5^{\prime}$ in üzerinde stabilitesinin bozulduğunu ve topraktaki kalsiyumun șelattaki demirin yerine geçtiğini tespit etmiștir.

Bu çalıșmanın amacı Bafra, Çarșamba ve Suluova topraklarında fasülye bitkisinin demirli gübrelemeye responsu ile toprakların kloroz indis değerleri ve bazı özellikleri arasındaki ilișkilerin belirlenmesidir.

\section{MATERYAL ve YÖNTEM}

Deneme toprakları Bafra, Çarșamba ve Suluova ilçelerinin tarım arazilerinde $0-20 \mathrm{~cm}$ toprak derinliğinden sert plastik bir kürekle alınmıștır. Topraklarda bünye Bouyoucos (1951), toprak reaksiyonu Jackson (1962), toplam kireç Hızalan ve Ünal (1966), aktif kireç Drouineau (1942), organik madde Chapman ve Pratt (1961), alınabilir fosfor Olsen vd., (1954) ve alınabilir demir 0,005M DTPA+0,0 $1 \mathrm{M} \mathrm{CaCl}_{2}+0,1 \mathrm{M}$ TEA, $(\mathrm{pH}=7,3)$ ekstraksiyon yöntemiyle Lindsay ve Norvell (1969) tarafından bildirildiği gibi belirlenmiștir. Ayrıca kloroz indeks-1 ve indeks-2 değerleri Loué (1986)'da bildirildiği șekilde așağıdaki formüle (eșitlik 1) göre hesaplanmıștır.

$\mathrm{KiD}=\frac{A \cdot 10^{4}}{B^{2}}$

$\mathrm{KID}=$ Kloroz indeks değeri

$A=$ Aktif kirec $(\%)$

$\mathrm{B}=$ Kolayca ekstrakte edilebilir demir $\left(\mathrm{mg} \mathrm{kg}^{-1}\right)$

Bu formülde kloroz indeks-1 değerleri hesaplanırken kolayca ekstrakte edilebilir demir kapsamları 0.05M EDTA ile ekstrakte edilmiș, indeks2 değerleri hesaplanırken ise kolayca ekstrakte edilebilir demir kapsamları 0,2 N amonyum okzalat ile ekstrakte edilmiștir (Loué, 1986).

Tesadüf parselleri deneme desenine göre üç tekerrürlü olarak yapılan sera denemesinde plastik saksılara $4600 \mathrm{~g}$ tam kuru toprak konulmuștur. Bütün saksılara ekimden önce $100 \mathrm{mg} \mathrm{kg}^{-1} \mathrm{~N}$ (amonyum nitrat), $200 \mathrm{mg} \mathrm{kg}^{-1} \mathrm{~K}$ (potasyum sülfat) verilmiștir. Deneme toprakları, 15 no' lu toprak hariç, yarayıș̦lı fosfor kapsamları yönünden yeterli bulunmuștur. Bu nedenle saksı denemesinde topraklara fosforlu gübre verilmemiștir. Denemede topraklara $\mathrm{Fe}_{0}$ : 0 (kontrol), $\mathrm{Fe}_{1}: 2, \mathrm{Fe}_{2}: 4$ ve $\mathrm{Fe}_{3}: 8 \mathrm{mg} \mathrm{kg}^{-1}$ dozlarında Fe-EDDHA formunda demir (Fe) uygulanmıștır. Her saksıya 6 adet fasülye tohumu (Phaseolus vulgaris L. var. nanus) ekilmiștir. Daha sonra her saksıda 2 bitki bırakılarak seyreltme yapılmıștır. Denemeye 80 gün devam edilmiș ve bu süre içerisinde saksılar her gün tartılarak tarla kapasitesinde tutulmuștur. Deneme bitiminde bitkiler toprak hizasından çelik makasla kesilerek hasat edilmiș ve $65^{\circ} \mathrm{C}^{\prime}$ de etüvde kurutulmuștur. Kontrol ve farklı dozlarda demirli gübre uygulayarak yetiștirilen fasulye bitkisinin kuru madde miktarları belirlendikten sonra, deneme topraklarında demirli gübrelemeyle kuru maddede sağlanan \% değișim değerleri așağıdaki formüle (eșitlik 2) göre hesaplanmıștır.

$$
\begin{aligned}
& \mathrm{KGD}=\frac{(A-B)}{B} \times 100 \\
& K G D=\text { Kontrole Göre Değișim (\%) }
\end{aligned}
$$

$A=$ Demirli gübreleme ile elde edilen kuru madde miktarı (g/saksı)

$\mathrm{B}=$ Kontrolde $\left(\mathrm{Fe}_{0}\right)$ elde edilen kuru madde miktarı (g/saksı)

Denemeden elde edilen sonuçların korelasyon ve regresyon analizleri Yurtsever (1984)'e göre yapılmıștır.

\section{BULGULAR ve TARTIȘMA}

\section{Deneme Topraklarının Bazı Fiziksel ve Kimyasal Özellikleri}

Deneme topraklarının bazı fiziksel ve kimyasal özellikleri Çizelge 1'de verilmiștir. Çizelge 1 incelendiğinde kil bünyeli topraklar Çarșamba'dan alınanların \% 30'unu, Bafra'dan alınanların \% 33'ünü, Suluova'dan alınanların \% 42.9' unu olușturmuștur. Killi tın bünyeli topraklar ise Çarșamba'dan alınanların \% 30'unu, Bafra'dan alınanların \% 44.4' ünü, Suluova'dan alınanların \% 28.6'sını teșkil etmiștir. Tın bünyeli topraklar ise Çarșamba'dan alınanların \% 10'unu, Bafra'dan alınanların \% 11,1'ini, Suluova'dan alınanların \% 28,6' sını olușturmuștur. Ayrıca Çarșamba'dan alınan toprakların \% 30'u siltli kil, \% 20'si siltli tınlı bir bünyeye sahip, Bafra'dan alınan toprakların ise \% 11,1'i kumlu tın bünyeye sahiptir. Buna göre deneme topraklarının büyük bir kısmı kil ve killi tın bünyelidir. 
Cizelge 1. Deneme toprakların bazı fiziksel ve kimyasal özellikleri

Table 1. Some of the physical and chemical properties of experiment soils

\begin{tabular}{|c|c|c|c|c|c|c|c|c|c|c|}
\hline $\begin{array}{c}\text { Top. } \\
\text { No }\end{array}$ & Alındığı yer & $\begin{array}{c}\text { Kum } \\
\%\end{array}$ & $\begin{array}{l}\text { Silt } \\
\%\end{array}$ & $\begin{array}{l}\text { Kil } \\
\%\end{array}$ & $\mathrm{pH}$ & $\begin{array}{c}\text { Toplam } \\
\text { Kireç } \\
\%\end{array}$ & $\begin{array}{c}\text { Aktif } \\
\text { kireç } \\
\%\end{array}$ & $\begin{array}{c}\text { Org. } \\
\text { madde } \\
\%\end{array}$ & $\begin{array}{c}\text { Yarayıșlı } \\
\text { Fe } \\
\text { mg kg k}^{-1}\end{array}$ & $\begin{array}{c}\text { Alınabilir } \\
\mathrm{P}_{2} \mathrm{O}_{5} \\
\mathrm{~kg} / \mathrm{da}^{-1}\end{array}$ \\
\hline 1 & Çarșamba(Çınarcık) & 32,5 & 37,0 & 30,5 & 7,6 & 15,5 & 7,3 & 1,3 & 15,4 & 7,2 \\
\hline 2 & Çarșamba (Karabahçe) & 15,7 & 60,3 & 24,0 & 6,9 & 3,2 & 3,0 & 2,7 & 19,5 & 15,2 \\
\hline 3 & Çarșamba (Ovacık) & 24,3 & 27,4 & 48,3 & 6,9 & 1,3 & 2,3 & 2,2 & 41,4 & 42,9 \\
\hline 4 & Çarșamba (Hürriyet) & 28,2 & 39,2 & 32,6 & 6,6 & 6,0 & 4,4 & 1,6 & 13,6 & 18,4 \\
\hline 5 & Çarșamba (Ahubaba) & 18,0 & 36,4 & 45,6 & 6,5 & 0,5 & 3,5 & 2,4 & 15,6 & 24,1 \\
\hline 6 & Suluova (Saluca) & 36,7 & 27,3 & 36,0 & 7,6 & 16,5 & 9,8 & 1,9 & 4,4 & 14,4 \\
\hline 7 & Suluova (Uzunoba) & 25,0 & 22,8 & 52,2 & 7,3 & 16,1 & 12,9 & 1,6 & 4,9 & 137,6 \\
\hline 8 & Suluova (Yüzbey) & 32,9 & 42,6 & 24,5 & 7,5 & 12,3 & 6,5 & 1,1 & 8,0 & 18,2 \\
\hline 9 & Suluova (Kurnaz) & 34,5 & 27,8 & 37,7 & 7,2 & 15,3 & 10,2 & 1,5 & 4,8 & 14,3 \\
\hline 10 & Suluova (Saygılı) & 29,4 & 27,0 & 43,6 & 6,9 & 9,5 & 7,1 & 2,3 & 3,9 & 29,2 \\
\hline 11 & Suluova (Eraslan) & 14,5 & 25,0 & 60,6 & 7,5 & 11,8 & 9,1 & 2,1 & 7,3 & 25,4 \\
\hline 12 & Suluova (Hacıbayram) & 46,6 & 28,9 & 24,5 & 7,4 & 9,1 & 4,5 & 2,3 & 6,4 & 10,4 \\
\hline 13 & Çarșamba(Kurtahmetli) & 13,9 & 36,5 & 49,6 & 6,8 & 0,9 & 2,5 & 2,0 & 15,6 & 52,0 \\
\hline 14 & Çarșamba (Mușçalı1) & 9,4 & 49,0 & 41,6 & 7,7 & 10,8 & 8,7 & 2,5 & 29,2 & 6,3 \\
\hline 15 & Çarșamba (Bafraçalı) & 32,2 & 46,0 & 21,8 & 7,3 & 6,3 & 3,3 & 0,8 & 11,7 & 2,0 \\
\hline 16 & Çarșamba (Mușçalı2) & 23,0 & 55,0 & 21,9 & 7,2 & 7,8 & 3,8 & 2,5 & 35,7 & 12,6 \\
\hline 17 & Çarșamba (Y. Donurlu) & 35,3 & 36,0 & 28,7 & 7,6 & 1,2 & 2,0 & 1,6 & 14,2 & 7,7 \\
\hline 18 & Bafra (Doğanca 1) & 15,7 & 20,3 & 64,0 & 7,1 & 0,0 & 2,3 & 3,0 & 30,3 & 17,6 \\
\hline 19 & Bafra (Koșuköyü) & 34,5 & 45,6 & 19,9 & 7,7 & 10,5 & 4,0 & 1,9 & 15,6 & 10,4 \\
\hline 20 & Bafra (Șeyhören) & 26,5 & 30,1 & 45,3 & 7,6 & 2,2 & 3,5 & 2,3 & 13,4 & 28,4 \\
\hline 21 & Bafra (Kalaycalı) & 23,4 & 44,0 & 32,6 & 7,3 & 7,2 & 4,4 & 2,4 & 9,3 & 12,0 \\
\hline 22 & Bafra (Adaköyü) & 22,9 & 44,5 & 32,6 & 7,4 & 10,5 & 6,0 & 2,5 & 15,9 & 13,6 \\
\hline 23 & Bafra (Fenerköyü) & 56,8 & 35,7 & 7,50 & 7,2 & 10,3 & 3,0 & 0,7 & 5,3 & 20,8 \\
\hline 24 & Bafra (Sarıkaya) & 19,7 & 45,3 & 35,0 & 5,2 & 0,0 & 2,4 & 2,0 & 33,3 & 51,9 \\
\hline 25 & Bafra (Doğanca2) & 22,5 & 38,0 & 39,5 & 7,3 & 0,3 & 1,8 & 2,2 & 42,5 & 17,3 \\
\hline 26 & Bafra (Sahilkent) & 13,4 & 29,0 & 57,6 & 6,7 & 4,8 & 4,9 & 4,1 & 21,9 & 23,3 \\
\hline
\end{tabular}

$\mathrm{pH}$ değerleri 6-7 aralığında olan topraklar Carșamba'dan alınanların \% 50'sini, Bafra'dan alınanların \% 11, 1'ini ve Suluova'dan alınanların \% 11,3'ünü olușturmuștur. PH'sı 7-8 aralığında olan topraklar Carșamba'dan alınanların \% 50'sini, Bafra'dan alınanların \% 77,8'ini, Suluova'dan alınanların \%85,7'sini olușturmuștur. pH'sı 5-6 aralığında olan topraklar sadece Bafra'dan alınmıș ve alınan toprakların \% 11,1'ini olușturmuștur. Buna göre alınan toprakların büyük bir kısmının pH'sı 7-8 arasındadır.

Deneme topraklarının kireç kapsamları çoğunlukla \% 5-15 arasında bulunmakla beraber Suluova'dan alınanların yaklașık yarısı \% arasında ve diğer yarısının ise \% 15-25 arasında kireç içerdiği görülmüștür. \% 5-15 arası kireç içeren topraklar Çarșamba'dan alınanların \% 40'ını, Bafra'dan alınanların \% 44,4' ünü, Suluovadan alınanların \% 57, 1'ini olușturmuștur. \% 15-25 arası kireç kapsayan topraklar ise Çarșamba'dan alınanların \% 10 'unu, Suluova'dan alınanın \% 42, 9' unu kapsamıștır. Bafra'dan alınan topraklar bu aralıkta kireç içermemiștir. Diğer yandan \%1'den az kireç kapsayan topraklar Carșamba'dan alınanların \% 20'sini, Bafra'dan alınanların \% 33,3' ünü teșkil etmiș, \% 1-5 arası kirec kapsayan topraklar ise Carșamba'dan alınanın \% 30'unu, Bafra'dan alınanın \% 22,2'sini olușturmuștur. Suluova'dan alınan topraklar arasında \%1'in altında ve \% 1-5 arası kireç kapsayan topraklara rastlanmamıștır.

Deneme topraklarının organik madde kapsamları çoğunlukla orta düzeyde olup \% 2-3 arasında bulunmuștur. Orta düzeyde organik madde içeriğine sahip topraklar Çarșamba'dan alınanların \% 60'ını, Bafra'dan alınanın \% 55,6' sını, Suluova'dan alınanın \% 42,9'unu teșkil etmiștir. Organik madde kapsamı \% 1-2 arası fakir topraklar ise Çarșamba'dan alınanın \% 30'unu, Bafra'dan alınanın \% 11,1' ini, Suluova'dan alınanın \% 57, 1'ini teșkil etmiștir. Ayrıca \% 1'in altında çok düșük düzeyde organik madde kapsayan topraklar Çarșamba'dan alınanın \% 10'unu, Bafra'dan 
alınanın \% 11, 1'ini olușturmuștur. Ayrıca Bafra'dan alınan toprakların \% 11,1'i \% 3-4 arasında yüksek düzeyde; \% 11,1'i ise \% 4'den fazla çok yüksek düzeyde organik madde içermiștir. Çarșamba'dan alınan toprakların \% 60'ı, Bafra'dan alınanın \% 78'i, Suluova'dan alınan \% 85,7' si alınabilir fosfor kapsamları bakımından çok yüksektir. Çarșamba'dan alınan toprakların \% 10'unun çok az düzeyde fosfor içerdiği, \% 30'unun orta düzeyde fosfor içerdiği belirlenmiștir. Bafra ve Suluova topraklarının alınabilir fosfor kapsamları çoğunlukla yüksek bulunmuș olup, bu durum uzun süreden beri yapılan șekerpancarı yetiștiriciliğinde așırı fosforlu gübre kullanımına bağlanmıștır,

Lindsay ve Norvell (1972) yöntemi için Boer ve Reissenauer (1973) tarafından kritik düzey olarak verilen sınır değerine göre $\left(6 \mathrm{mg} \mathrm{kg}^{-1} \mathrm{Fe}\right)$ SuluovaSaluca, Uzunoba, Kurnaz, ve Saygılı'dan alınan topraklarla, Bafra- Fenerköyü toprakları noksanlık düzeyinde demir kapsamıștır. Bafra'dan alınan toprakların \%11,1' inin Suluova'dan alınan toprakların \% 57, 1'inin DTPA ile ekstrakte edilebilir demir kapsamı $6 \mathrm{mg} \mathrm{kg}^{-1}$ 'dan düșük bulunmuștur. Çarșamba'dan alınan toprakların hepsi $6 \mathrm{mg} \mathrm{kg}^{-1}$ ın üzerinde demir içermiștir.

Louê (1986) tarafından DTPA yöntemi için bildirilen topraktaki yarayıșlı demiri değerlendirme kriterlerine göre, $10 \mathrm{mg} \mathrm{kg}^{-1}$ 'dan az demir kapsayan Suluova'nın Saluca, Uzunoba, Yüzbey, Kurnaz, Saygılı, Eraslan, Hacıbayram ile Bafra'nın Kalaycılı, Fenerköyü mevki topraklarında demir noksanlığı riski yüksek bulunmuștur. Bununla beraber 10-20 mg kg-1 arası demir kapsayan Çarșamba'nın Çınarcık, Karabahçe, Hürriyet,Ahubaba, Kurtahmetli, Bafraçall, Y. Donurlu ile Bafra'nın Koșuköyü, Șeyhören ve Adaköyü topraklarında çok düșük de olsa demir noksanlığı riski vardır. Nitekim sera koșullarında 1, 3, $4,5,6,7,8,9,10,11,12,13,14,15,17,18,20$, $21,22,23$ ve 26 numaralı topraklarda yetiștirilen fasülye bitkisi demirli gübrelemeye olumlu cevap vermiștir.

\section{Toprakların Kloroz İndis 2 Değerlerine Bağlı Olarak Fasülye Bitkisinin Demirli Gübrelemeye Responsu}

Toprakların kloroz indeks 2 değerlerine bağlı olarak fasülye bitkisinin demirli gübrelemeye responsunu ortaya koyan değerler Çizelge 2'de verilmiștir. Çizelge 1 ve Çizelge 2' nin birlikte incelenmesinden görüleceği gibi, demir uygulaması ile kuru maddede \% 20'nin üzerinde sağlanan artıș değerleri ortalama \% 20,02 ile \% 61,01 arasında değișmiștir. Demir uygulaması ile bu seviyelerde artıș gösteren topraklar deneme topraklarının \% 46, $15^{\prime}$ ini olușturmuștur. Demir uygulaması ile kontrole oranla sağlanan \% değișim Suluova topraklarında daha yüksek bulunmuștur (Suluova topraklarında ortalama \% 37,2; Carșamba topraklarında ortalama $\% 15,4$ ve Bafra topraklarında ise ortalama $\% 5,4)$. Çarșamba'dan alınan toprakların \% 40'ında, Bafra'dan alınan toprakların \% 22'sinde ve Suluova'dan alınan toprakların ise \% 85,7' sinde demir uygulaması ile kuru maddede \% 20'nin üzerinde artıș sağlanmıștır.

Yapılan değerlendirmelere göre demir uygulaması ile kuru maddede tanığa oranla \% 20'nin üzerinde artıș sağlayan topraklar \% 1'in altında kireç kapsayan toprakların \% 20'sini; \% 1-5 arası kireç kapsayan toprakların \% 40'ını; \% 5-15 arası kireç kapsayan toprakların \% 41,7'sini; \% 1525 arası kireç kapsayan toprakların ise \% 100'ünü olușturmuștur. Eyüpoğlu vd., (1998), kireç kapsamı $\%$ 25'ten fazla olan toprakların \% 45,51'inde de'mir eksikliği sorunu var iken kireç kapsamı \% 1'den az olan toprakların ancak \% 8,42'sinde demir eksikliği sorunu görüldüğünü belirtmișlerdir. Araștırıcılar toprakların kireç kapsamları ile yarayıșlı demir kapsamları arasında önemli düzeyde, azalan bir ilișki olduğunu da saptamıșlardır. Diğer yandan kloroz ile toplam kalker arasında genel olarak ilișki olmadığı, buna karșın aktif kalkerin 120 mikrondan daha küçük çapa sahip kalker partikülleri) toprakların kloroza neden olma gücü üzerine daha etkili olduğu bildirilmiștir (Drouineau, 1942).

pH'ları 5-6 arasında olan toprakların hiçbirinde demir uygulaması ile ürün artıșı sağlanamazken; $\mathrm{pH}$ değerleri 6-7 arası toprakların \% 42,9'unda, $\mathrm{pH}$ değerleri 7-8 arası toprakların ise \% 50, 1 'inde demir uygulaması ile \% 20' nin üzerinde artıș sağlanmıștır. Eyüpoğlu vd., (1998) yarayıșlı demir kapsamı 4,5 mg kg-1'ın altında olan örneklerin \% miktarına göre demir eksikliğinin en fazla pH'sı 7-8 arasında değișen topraklarda görüldüğünü $(\% 31,17)$, bunu sırası ile pH'sı 8' dan büyük topraklar $(\% 26,67)$ ve $\mathrm{pH}^{\prime}$ 'sı 67 arasında değișen toprakların (\% 5,39) izlediğini bildirmișlerdir. Kalkerli toprakların çözeltilerinde yüksek seviyede karbonat, kalsiyum bulunduğu ve $\mathrm{pH}$ değerlerinin yüksek olduğu saptanmıș ve bu topraklarda demir klorozunun ortaya çıııșinda çözünebilir kalsiyumun bikarbonat iyonlarının, karbondioksitin ve fosforun etkili olduğu belirtilmiștir (Wallace ve Lunt, 1960). 
Cizelge 2. Demir uygulamasıyla kontrole göre kuru maddede sağlanan değișim değerleri ve toprakların kloroz indeks değerleri

Table 2. Exchange and chlorosis index values provided in dry matter compared to the control by the application of iron

\begin{tabular}{|c|c|c|c|c|c|c|}
\hline \multirow[t]{2}{*}{ Toprak no } & \multicolumn{2}{|c|}{$\begin{array}{c}\text { Toprakların kloroz indeks } \\
\text { değerleri }\end{array}$} & \multicolumn{4}{|c|}{$\begin{array}{l}\text { Demirli gübreleme ile kontrole oranla kuru maddede sağlanan } \\
\text { değișim, \% } \\
\text { Demir Dozları, } \mathrm{mg} \mathrm{kg}^{-1}\end{array}$} \\
\hline & İndeks 1 & İndeks 2 & 2 & 4 & 8 & Ortalama respons, $\%$ \\
\hline 1 & 34,08 & 215.47 & 65.14 & 81.65 & 36.24 & 61.01 \\
\hline 2 & 1,97 & 15.11 & -13.63 & -25.72 & -14.26 & -17.87 \\
\hline 3 & 0,04 & 3.93 & 27.84 & 23.79 & 21.77 & 24.47 \\
\hline 4 & 7,40 & 35.19 & 36.02 & 42.79 & 31.31 & 36.70 \\
\hline 5 & 0,26 & 22.19 & 21.27 & 19.58 & 38.23 & 26.30 \\
\hline 6 & 88,70 & 124.17 & 42.00 & 61.43 & 28.05 & 43.83 \\
\hline 7 & 227,74 & 311.69 & 33.06 & 49.55 & 56.46 & 46.36 \\
\hline 8 & 32,27 & 200.20 & 43.20 & 37.60 & 66.78 & 49.19 \\
\hline 9 & 118,01 & 673.86 & 70.15 & 26.55 & 29.14 & 41.95 \\
\hline 10 & 94,92 & 183.59 & -8.17 & 12.19 & 20.08 & 8.03 \\
\hline 11 & 122,10 & 209.77 & 32.68 & 72.03 & 49.07 & 51.26 \\
\hline 12 & 13,61 & 73.74 & 36.25 & 26.30 & -42.47 & 20.02 \\
\hline 13 & 0,98 & 2.09 & -2.20 & -1.02 & 5.02 & 0.60 \\
\hline 14 & 23,92 & 24.91 & 31.66 & -2.64 & 5.01 & 11.35 \\
\hline 15 & 9,74 & 54.08 & -1.40 & 40.89 & -12.07 & 9.14 \\
\hline 16 & 3,26 & 46.53 & -2.25 & -17.22 & 12.95 & -2.17 \\
\hline 17 & 1,28 & 16.44 & -10.42 & 0.42 & 22.08 & 4.03 \\
\hline 18 & 0,04 & 6.48 & 3.25 & 9.66 & -10.78 & 0.71 \\
\hline 19 & 13,03 & 66.06 & -21.42 & -35.94 & -7.48 & -21.61 \\
\hline 20 & 1,68 & 55.17 & 1.44 & 35.58 & 30.11 & 22.38 \\
\hline 21 & 18,26 & 158.48 & 14.68 & 37.66 & 50.24 & 34.19 \\
\hline 22 & 22,28 & 256.10 & 12.80 & 7.31 & 22.58 & 14.23 \\
\hline 23 & 4,69 & 12.05 & 5.65 & 21.16 & -21.73 & 1.70 \\
\hline 24 & 1,17 & 4.10 & -2.97 & -1.12 & 0.12 & -1.32 \\
\hline 25 & 0,07 & 1.37 & -5.65 & -27.63 & -26.53 & -19.94 \\
\hline 26 & 5,55 & 4.39 & 26.26 & 3.15 & 25.41 & 18.27 \\
\hline
\end{tabular}

Demir uygulaması ile kuru maddede \% 20'nin üzerinde artıs sağlanan toprakların \% 34,6' sında kloroz gösterme indeks-2 değerleri 55, 17-673,86 arasında, \% 11,53' ünde ise 3,93-35, 19 arasında bulunmuștur. Demir uygulaması ile kuru maddede $\%$ 20' nin üzerinde artıș sağlanan toprakların $\%$ 42,31' inde DTPA ile belirlenen yarayıșlı demir kapsamı 4,4-15,6 $\mathrm{mg} \mathrm{kg}^{-1}$ arasında bulunmuș, \% 3,84 'ünde ise 41,4 $\mathrm{mg} \mathrm{kg}^{-1}$ bulunmuștur. Loué (1986), DTPA ekstraksiyon yöntemiyle belirlenen yarayıșlı demir kapsamının 10 mg kg-1'ın altında olması halinde demir noksanlık riskinin yüksek; $10-$ $20 \mathrm{mg} \mathrm{kg}^{-1}$ arasında olması halinde noksanlık riskinin orta veya düșük seviyede olduğunu belirtmiș, 20$150 \mathrm{mg} \mathrm{kg}^{-1}$ arasında yarayıșlı demirin yeterli olacağını bildirmiștir. Araștırıcı DTPA yöntemi ile belirlenen yarayıșlı demirin $150 \mathrm{mg} \mathrm{kg}^{-1}$ 'ın üzerinde olması halinde arazide su baskınının ve bazı problemlerin olabileceğini de belirtmiștir. Bununla birlikte Boer ve Reisenauer (1973), DTPA yöntemi için kritik demir düzeyinin 5-6 mg kg-1 olduğunu, bu seviyenin üzerinde demir içeren topraklarda demir klorozu görülmediğini bildirmișlerdir. Buna karșın Lindsay ve Norvell, (1969) tarafından belirtilen 0,005 M DTPA +0,01 $\mathrm{M} \mathrm{CaCl}_{2}+0,1 \mathrm{M}$ Triethanolamin $(\mathrm{pH} 7,3)$ yöntemi için kritik değerin Lindsay (1979) tarafından 4,5 mg kg-1 olduğunu ve $4,5 \mathrm{mg} \mathrm{kg}^{-1}$ ın üzerinde demir içeren topraklarda demirli gübrelemeye respons alınmadığını bildirilmiștir.

\section{Demirli Gübrelemeye Respons Değerleri ile Kloroz İndeks Değerleri ve Bazı Toprak Özellikleri Arasındaki ìlișki}

Demirli gübrelemeye respons değerleri ile bazı toprak özellikleri ve kloroz indeks değerleri arasındaki ilișkileri gösteren korelasyon katsayıları Çizelge 3'de verilmiștir. Çizelgenin incelenmesinden de görüleceği gibi, toprakların toplam kireç, aktif kireç kapsamları ve kloroz indeks-2 değerleri ile demirli gübrelemeyle kuru maddede sağlanan \% değișim değerleri arasında pozitif ve önemli ilișkiler saptanmıștır. 
Cizelge 3. Demirli gübrelemeye ortalama respons değerleri ile bazı toprak özellikleri ve kloroz indeks değerleri arasındaki ilișkileri gösteren korelasyon katsayıları (r)

Table 3. Correlation coefficients which showed the associations between average responding values obtained by iron fertilization and some soil characteristics and chlorosis index values (r)

\begin{tabular}{lc}
\hline Toprak Özellikleri & Ortalama respons değerleri, \% \\
\hline pH (1:2.5 toprak-saf su) & 0,202 \\
Toplam kireç, \% & $0,584^{* *}$ \\
Aktif kireç, \% & $0,666^{* *}$ \\
Kil, \% & 0,243 \\
Kum \% & 0,110 \\
Silt, \% & $-0,442^{*}$ \\
Organik madde, \% & $-0,257$ \\
Alınabilir fosfor & 0,179 \\
Kloroz indis -1 & $0,536^{* *}$ \\
Kloroz indis -2 & $0,557^{* *}$ \\
Yarayıșlı demir, mg kg-1 & $-0,491^{* *}$ \\
\hline
\end{tabular}

Bu ilișkilerin korelasyon katsayıları sırası ile $r=0,584^{* *}, r=0,666^{* *}$ ve $r=0,557 * *$ olup, toprakların toplam kireç, aktif kireç kapsamları ve kloroz indeks-2 değerleri arttıkça demirli gübrelemeye respons değerleri artmıștır. Diğer bir ifadeyle demirli gübrelemeyle kuru maddede sağlanan \% artıș değerleri toprakların toplam ve aktif kireç kapsamları ve kloroz indeks-2 değerleri arttıkça artmıștır ve bu artıș değerleri istatistiksel olarak önemli bulunmuștur (Șekil 1, 2, 3).

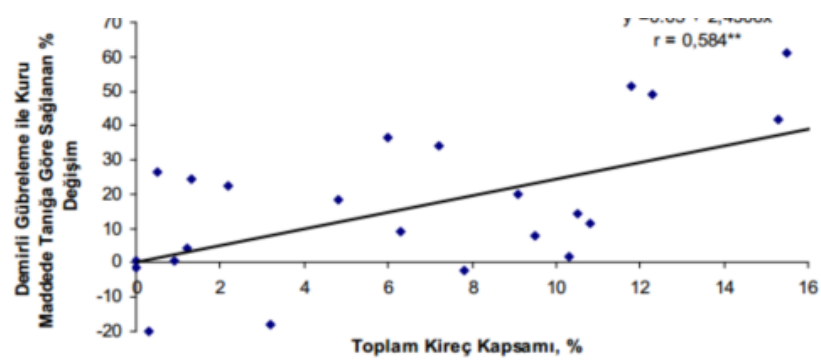

Șekil 1. Toprakların toplam kireç kapsamları ile demirli gübrelemeye respons değerleri arasındaki ilișki

Figure 1. The relationship between total lime content of the soils and responsabile values to iron fertilization

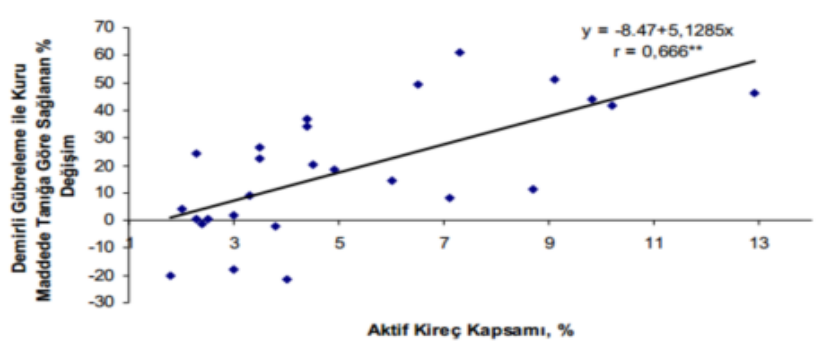

Sekil 2. Toprakların aktif kireç kapsamları ile demirli gübrelemeye respons değerleri arasındaki ilișki

Figure 2. The relationship between active lime content of the soils and responsabile values to iron fertilization

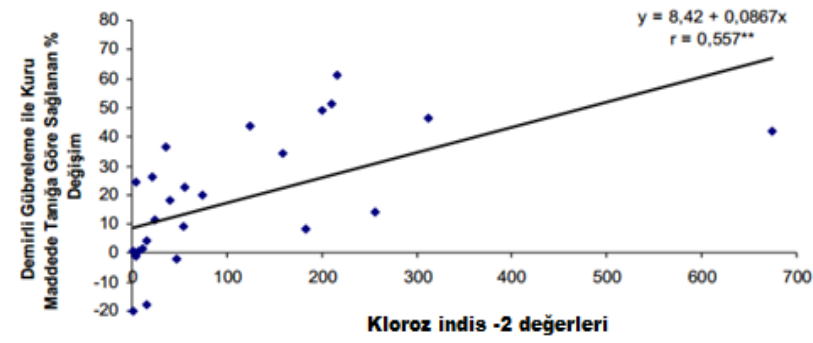

Sekil 3. Toprakların kloroz indeks-2 değerleri ile demirli gübrelemeye respons değerleri arasındaki ilișki

Figure 3. The relationship between chlorosis index-2 values of the soils and responsabile values to iron fertilization

Toprakların kloroz olușturma gücünü gösteren indeks-1 ve indeks-2 değerleri arttıkça. demirli gübreleme fasülye bitkisinin kuru madde miktarında artıșlar meydana getirmiștir. İndeks-1 ve indeks-2 değerlerinin önemli olduğu tespit edilmiștir. Juste ve Pouget (1972) tarafından toprakların kloroz indeks değerlerinin belirlenmesinin önemli olacağı ve bu indeksin belirlenmesinde toprakların aktif kireç kapsamı ile amonyum okzalatla kolayca ekstrakte edilebilir demir kapsamının birlikte kullanılması gerektiği bildirilmiștir.

Toprakların silt ve yarayıșlı demir kapsamları ile demirli gübrelemeye respons değerleri arasında önemli ve negatif ilișkiler belirlenmiștir. Bu ilișkilerin korelasyon katsayıları sırası ile $r=-0.442$ * ve -0.491 * * olup, toprakların silt ve yarayıșlı demir kapsamları arttıkça bitkide demirli gübrelemeyle sağlanan artıș değerleri azalmıștır (Șekil 4). Toprakların alınabilir fosfor kapsamları ile demirli gübrelemeye respons değerleri arasında önemli bir ilișki belirlenmemiștir. 


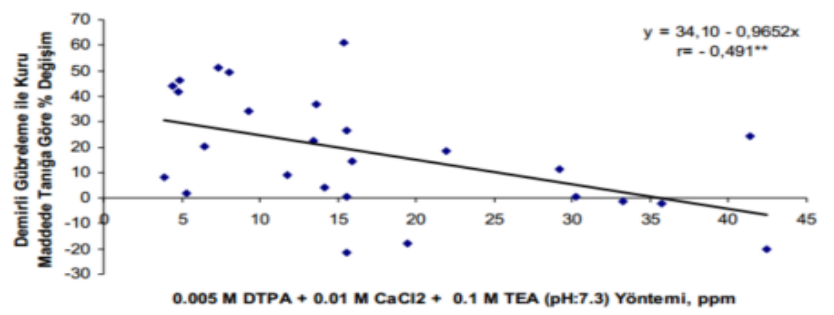

Sekil 4. Toprakların yarayıșlı demir kapsamları ile demirli gübrelemeye respons değerleri arasındaki ilișki

Figure 4. The relationship between the available iron content of soils and responsabile values to iron fertilization

\section{Toprakların Kloroz Indeks Değerleri ile Bazı Özellikleri Arasındaki ìlișki}

Toprakların kloroz indeks değerleri ile bazı özellikleri arasındaki ilișkilerin korelasyon katsayıları Çizelge 4'te verilmiștir. Çizelgenin incelenmesinden de görüleceği gibi toprakların kloroz indeks-2 değerleri ile yarayıșlı demir kapsamları arasındaki ilișkinin korelasyon katsayısı $r=-0,499 * *$ olup, negatif ve önemli bulunmuștur. Diğer bir ifadeyle toprakların yarayıșlı demir kapsamları arttıkça kloroz indeks-2 değerleri azalmıștır.

Aynı șekilde toprakların kloroz indeks değerleri ile silt ve organik madde kapsamları arasında önemsiz olmakla birlikte negatif ilișkiler saptanmıștır. Toprakların silt ve organik madde kapsamları arttıkça kloroz indeks değerleri azalmaktadır. Eyüpoğlu vd., (1998) tarafından organik madde fazlalığının demir eksikliğini azaltan bir faktör olduğu belirtilmiș, demir eksikliği sorununun en fazla organik madde kapsamı \% 1' den az olan topraklarda görüldüğü bildirilmiștir. Organik madde kapsamı \% 1'den az olan toprakların \% 37,22' sinde demir eksikliği sorunu varken, organik madde kapsamı \% 4' ün üzerine çıkan topraklarda demir eksikliği sorunu toprakların ancak \% $5^{\prime}$ inde görülmektedir. Toprakların organik madde kapsamları ile yarayıșlı demir kapsamları arasında önemli düzeyde artan bir ilișki saptanmıștır. Toprakların organik madde kapsamı artııça yarayıșlı demir kapsamının arttığı belirtilmiștir.

Çalıșmada toprakların kloroz indeks değerleri ile toplam ve aktif kireç kapsamları arasında pozitif önemli ilișkiler saptanmıștır. Bu ilișkilerin korelasyon katsayıları indeks-2 için sırası ile $r=0,681^{* *}$ ve $r=0,729^{* *}$, indeks -1 için ise sırası ile $r=0,683^{* *}$ ve $r=0,887^{* *}$ olup, toprakların toplam ve aktif kireç kapsamları arttıkça kloroz indeks-1 ve indeks-2 değerleri artmıștır (Șekil 5, Șekil 6).

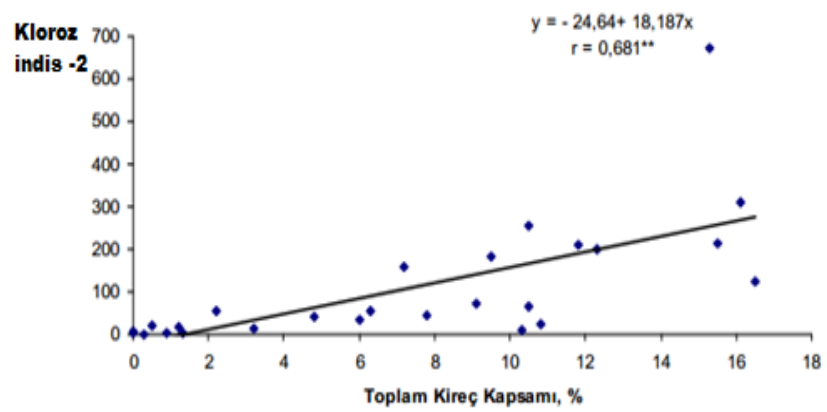

Șekil 5. Toprakların toplam kireç kapsamları ile kloroz indeks-2 değerleri arasındaki ilișki

Figure 5. The relationship between the total lime content and chlorosis index-2 values of the soils

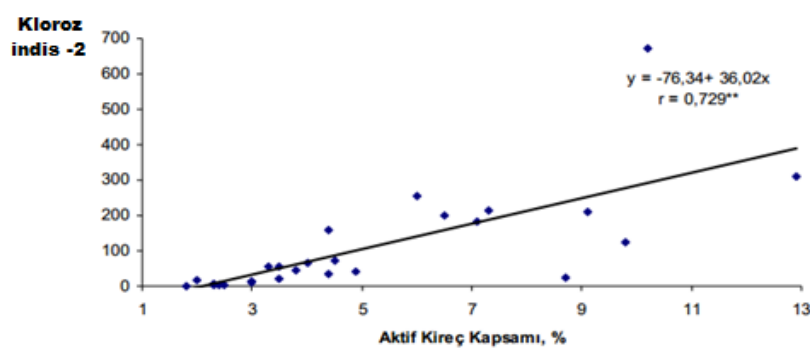

Șekil 6. Toprakların aktif kireç kapsamları ile kloroz indeks2 değerleri arasındaki ilișki

Figure 6. The relationship between the active lime content and chlorosis index-2 values of the soils

Cizelge 4. Toprakların kloroz indeks değerleri ile bazı özellikleri arasındaki ilișkilerin korelasyon katsayıları (r)

Table 4. The correlation coefficients between chlorosis index values and some properties of soils(r)

\begin{tabular}{lcc}
\hline Toprak özellikleri & Toprakların kloroz indis değeri-1 & Toprakların kloroz indis değeri-2 \\
\hline Yarayıșlı demir & $-0,508^{* *}$ & $-0,499^{* *}$ \\
Kum & 0,045 & 0,170 \\
Silt & $-0,472^{*}$ & $-0,277$ \\
Kil & 0,308 & 0,071 \\
pH & 0,205 & 0,235 \\
Toplam kireç & $0,683^{* *}$ & $0,681^{* *}$ \\
Aktif kireç & $0,887^{* *}$ & $0,729^{* *}$ \\
Organik madde & $-0,200$ & $-0,241$ \\
Alınabilir fosfor & $0,612^{* *}$ & 0,148 \\
\hline
\end{tabular}


Toprakların alınabilir fosfor kapsamları ile kloroz indis-1 değerleri arasında önemli pozitif ilișki belirlenmiș, fakat kloroz indis-2 değerleri arasındaki ilișki önemsiz bulunmuștur.

\section{Toprakların Yarayıșlı Demir Kapsamları ile Bazı Toprak Özellikleri Arasındaki İlișkiler}

Toprakların yarayıșlı demir kapsamları ile bazı toprak özellikleri arasındaki ilișkilerin korelasyon katsayıları (r) Çizelge 5’te verilmiștir.

Cizelge 5. Toprakların yarayıșlı demir kapsamları ile bazı toprak özellikleri arasındaki ilișkilerin korelasyon katsayıları (r)

Table 5. Correlation coefficients of the relationship between available iron contents of the soils and some soil properties $(r)$

\begin{tabular}{lc}
\hline Toprak Özellikleri & Yarayıșlı demir \\
\hline Kum & $-0,493^{* *}$ \\
Silt & 0,276 \\
Kil & 0,184 \\
pH & $-0,311$ \\
Toplam kireç & $-0,598^{* *}$ \\
Aktif kireç & $-0,517^{* *}$ \\
Organik madde & $0,406^{*}$ \\
Alınabilir fosfor & $-0,063$ \\
\hline
\end{tabular}

Çizelge $5^{\prime}$ in incelenmesinden de görüleceği gibi, toprakların yarayıșlı demir kapsamları ile kum, toplam kireç ve aktif kireç kapsamları arasındaki ilișkilerin korelasyon katsayları sırası ile $r=-0,493^{* *}$ ve $r=-0,598^{* *}$ ve $r=-0,517^{* *}$ olup, negatif ve önemli bulunmuștur. Diğer bir ifadeyle toprakların kum, toplam ve aktif kireç kapsamları arttıkça yarayıșlı demir kapsamları azalmıștır. Eyüpoğlu vd., (1998) toprakların kireç kapsamları arttıkça yarayıșlı demir kapsamları azaldığını, dolayısıyla da bir bitki besin maddesi olarak demire bitkilerin daha fazla gereksinim gösterdiklerini bildirmișlerdir. Araștırıcılar ayrıca yarayıșılı demir kapsamı 4,5 mg kg-1'ın altında kalan toprakların \% miktarına göre en fazla demir eksikliğinin kumlu topraklarda (\% 53,25) görüldüğünü belirtmișlerdir.

Çalıșmada toprakların yarayıșlı demir kapsamları ile silt, kil ve pH değerleri arasındaki ilișkiler önemsiz bulunmuștur. Toprakların yarayıșlı demir kapsamları ile organik madde kapsamları arasındaki ilișki ise pozitif ve önemli olup, korelasyon katsayısı $r=0,406$ * olarak belirlenmiștir. Diğer bir ifadeyle toprakların organik madde kapsamları arttıkça yarayıșlı demir kapsamları artmıștır. Sillanpaa (1972) tarafından mineral toprakların mikro element kapsamlarının organik madde miktarının artıșına bağlı olarak arttığı, fakat toprak organik madde miktarının \% 10 'u geçmesi durumunda artan organik maddeye bağlı olarak mikro element miktarının azaldığı belirtilmiștir. Eyüpoğlu vd., (1998) tarafından toprakların organik madde kapsamları arttıkça yarayıșlı demir kapsamlarının arttığı bildirilmiștir. Toprakların kloroz indeks 1 ve indeks 2 değerleri arasındaki ilișkinin korelasyon katsayısı $r=0.696^{* *}$ bulunmuștur.

\section{SONUCLAR}

Toprakların toplam ve aktif kireç kapsamları arttıkça yarayıșlı demir kapsamları azalmıș ve toprakların kloroz indis değerleri (indis-1 ve indis-2) artmıștır. Toprakların kloroz indis değerleri arttıkça fasülye bitkisi demirli gübrelemeye olumlu cevap vermiștir. Toprakların demir durumlarının belirlenmesinde ve demirli gübrelemeye olumlu cevap alınmasında toprakların kloroz olușturma gücünü gösteren indeks-1 ve indeks-2 değerlerinin kullanılabileceği sonucuna varılımıștır.

\section{Teșekkür}

Bu çalıșma Havva Sera Șendemirci tarafından Ondokuz Mayıs Üniversitesi Fen Bilimleri Enstitüsü Toprak ve Bitki Besleme Bölümünde yapılan doktora tezinin bir kısmını kapsamaktadır.

\section{KAYNAKLAR}

Bașar H (1997). Bitkilerde demir klorozu ve giderilme yöntemleri. Anadolu Dergisi T.C. Tarım ve Köyișleri Bakanlığı, Ege Tarımsal Araștırma Enstitüsü Müdürlüğü, İzmir.

Boer G J, Reisenauar H M (1973). DTPA as an exractant of available soil iron. Commun. Soil. Sci. Plant Anal. 4(2): 121-128.

Bouyoucos G J (1951). A recalibration of the hydrometer method for making mechanical analysis of soils. Agron. J. 43: 434-438.

Champagnol $F$ (1984). Troubles de la nutrition minerales de la vigne. In "Elements de physiologie de la vigne et de viticulture generale". Chap. III. pp. 174-198.

Chapman H D, Pratt PF (1961). Methods of analysis for soils. plants and waters. Univ. of California, Division of Agricultural Series. p. 1-309. USA.

Drouineau G (1942). Dosage rapide du calcaire actif des sols. Ann. Agron. 12:441-450.

Eyüpoğlu F, Talaz S, Kurucu N (1998). Türkiye topraklarının bitkiye yarayıșlı bazı mikro elementler ( $\mathrm{Fe}, \mathrm{Cu}, \mathrm{Zn}, \mathrm{Mn}$ ) bakımından genel durum. Köy Hiz. Genel Müd, Toprak ve Gübre Araștırma Enstitüsü Müdürlüğü, Ankara.

Hızalan E, Ünal H (1966). Topraklarda önemli kimyasal analizler. A.Ü. Zir. Fak. Yayınları: 278.

Jackson M L (1962). Soil chemical analysis. Prentice-Hall. Inc.

Juste C, Pouget R (1972) Appréciation du pouvoir chlorosant des sols par un nouvel indice faisant intervenir le calcaire actif et le fer facilement extractible. Application au choix des porte-greffes de la vigne. C.R. Acad. Agric. 58, 352-357.

Lindsay W L, Norvell W A (1969). Development of a DTPA micronutrient soil test. Agron. Abstr. 84

Lindsay $W L$ (1974). Role of chelation in micronutrient availability. In "The plant root and its environment". Univ. Pres. of Virginia. pp. 507 - 524 
Loué A (1986). Les Oligo-elements en agriculture. AgrtNathan Intenational, Paris.

Morlat R, Courbe C (1981). Caractérisation de quelqes composantes du potentiel cholorosant des differents milieux carbonates dans le vignoble du Val de Loire. Conn. Vigne et Vin 15 (4): 229-246.

Norvell W A (1972). Equilibria of metal chelates in soil solution. In "Micronutrient in Agriculture" Soil Sci. Soc. of America, Madison, USA, 6: 115-138.
Özgümüș A (1987). Bitkilerde demir klorozu. Uludağ Üniversitesi Zir. Fak. Derg. 6:117-128.

Sillanpaa M (1972). Trace elements in soils and agriculture. Soils Bull. F.A.O. p.67, Rome.

Yurtsever N (1 984). Deneysel istatistik metodları. Toprak ve Gübre Araștırma Enstitüsü Müdürlüğü Yayınları. Teknik Yayın No: 56. Ankara. 